\title{
Distributions, fluxes, and toxicities of heavy metals in sediment pore water from tributaries of the Ziya River system, northern China
}

\author{
Xiaolei Zhu ${ }^{1,2}$ • Baoqing Shan ${ }^{1} \cdot$ Wenzhong Tang ${ }^{1} \cdot$ Shanshan $\mathrm{Li}^{3} \cdot$ Nan Rong ${ }^{1,2}$
}

Received: 20 April 2015 / Accepted: 27 October 2015 / Published online: 14 November 2015

(C) Springer-Verlag Berlin Heidelberg 2015

\begin{abstract}
The distributions and mobilities of metals in pore water strongly influence the biogeochemical processes and bioavailabilities of metals at sediment-water interfaces. Heavy metal concentrations were measured in pore water samples from the Shaocun River (SR), the Wangyang River (WR), and the Xiao River (XR), tributaries of the Ziya River system, northern China. The aim was to assess heavy metal contamination in the system and the associated environmental risks. The mean $\mathrm{Cd}$, $\mathrm{Cr}, \mathrm{Cu}, \mathrm{Ni}, \mathrm{Pb}$, and $\mathrm{Zn}$ concentrations in all three tributaries were $0.373,57.1,37.7,20.4,14.0$, and $90.6 \mu \mathrm{g} / \mathrm{L}$, respectively. The calculated $\mathrm{Cd}, \mathrm{Cr}, \mathrm{Cu}, \mathrm{Ni}, \mathrm{Pb}$, and $\mathrm{Zn}$ diffusion fluxes in the rivers were -0.427 to 0.469 , -71.8 to $42.5,3.16$ to $86.6,5.29$ to $14.0,7.24$ to 19.0 , and -204 to $21.9 \mu \mathrm{g} /\left(\mathrm{m}^{2}\right.$ day $)$, respectively, showing that the pore water was a source of most of the metals to the water column. Only $\mathrm{Cu}$ and $\mathrm{Pb}$ in the $\mathrm{XR}$ and $\mathrm{Cu}$ in the WR exceeded the final chronic value recommended by the US Environmental Protection Agency, but the metals in the WR sediment could have caused toxic effects.
\end{abstract}

Responsible editor: Philippe Garrigues

Baoqing Shan

bqshan@rcees.ac.cn

Wenzhong Tang

wztang@rcees.ac.cn

1 State Key Laboratory of Environmental Aquatic Chemistry, Research Center for Eco-Environmental Sciences, Chinese Academy of Sciences, Beijing 100085, China

2 University of Chinese Academy of Science, Beijing 100049, China

3 Beijing Newatt Environment Engineering Co., Ltd, Beijing 100048, China
These results are likely to be useful to the authorities responsible for sustainable river management.

Keywords Pore water $\cdot$ Heavy metals $\cdot$ Ziya River $\cdot$ Diffusion fluxes

\section{Introduction}

The contamination of aquatic systems with heavy metals has become an important worldwide problem requiring urgent action because of the toxicities of heavy metals and their abilities to accumulate in biota. Once a metal is released into the aquatic environment, a portion of the metal will be transferred to sediment through being adsorbed onto suspended matter and the sedimentation of the suspended matter (Cortecci et al. 2009, Zwolsman et al. 1993). Metals in sediment will be present in both the particulate phase and the dissolved phase (i.e., in the pore water), and these phases will interact with each other and with the overlying water at the sedimentwater interface. The distributions and mobilities of metals in pore water play important roles in the overall cycling of metals at the sediment-water interface (Davis and Galloway 1993, Donahoe and Liu 1998). In particular, the fraction of a metal in the pore water is generally considered to be the main bioavailable fraction in the sediment, although only a very small amount of a heavy metal will be present in the dissolved state in pore water (Ankley et al. 1991, Hall 1996, Suresh et al. 2011, Wenholz and Crunkilton 1995). If the concentration of a metal in the pore water is higher than the concentration in the overlying water column, the concentration gradient between the pore water and the overlying water will cause the dissolved metal to be transported from the sediment to the overlying water (Ciceri et al. 1992, Lyons and Fitzgerald 1980, Sakellari et al. 2011). In order to understand the mobility 
and toxicity of metals in the river ecosystem, it is very important to understand the heavy metal fluxes that occur at the sediment-water interface (Blasco et al. 2000, Costello et al. 2015).

Intensive industrial and agricultural activities in a densely populated river basin can lead to enormous amounts of nutrients and heavy metals entering the riverine ecosystem (Kucuksezgin et al. 2008). The Haihe Basin is located in the political, economic, and cultural center of China. The Ziya River system (ZYS), which is a major water system in the Haihe Basin, has been significantly contaminated by heavy metals due to industrial development and rapid urbanization. Previous studies have already reported high metal contents in the sediments from the ZYS (Tang et al. 2015, Tang et al. 2014, Tang et al. 2013). The sediments of the ZYS have been considered to be high ecological risk due to heavy metals. However, until now, there have been few studies focused on the processes through which contaminants are released from sediment in the ZYS to the overlying water through the sediment-water interface.

Dissolved metals in pore water are potential sources of pollution because they can be liberated into the overlying water through complex and dynamic processes. Therefore, three typical tributaries of the ZYS characterized by different wastewater sources were selected to (1) investigate the concentrations of heavy metal in sediment pore water; (2) examine the diffusion fluxes of trace metals between the pore water in surface sediment and the overlying water; (3) assess the toxicities of trace elements in the pore water. The results will allow a better understanding to be gained of the role of sediments as a source or sink for metals in the ZYS and, consequently, to allow a better understanding to be gained of the influence of metals in the sediments on water quality in the ZYS..

\section{Materials and methods}

\section{Study area}

The ZYS is in Hebei Province, the economy of which has rapidly developed in recent years. Rapid urbanization and the development of heavy industries have caused water bodies in Hebei Province to become significantly polluted. Hebei Province is lacking in water resources, and the deterioration of water quality has exacerbated the effects of this shortage. The ZYS watershed covers an area of $2747 \mathrm{~km}^{2}$, and $70 \%$ of the long-term mean annual precipitation of $550 \mathrm{~mm}$ falls between July and September.

The study was focused on three important but heavily polluted rivers, the Shaocun River (SR), the Wangyang
River (WR), and the Xiao River (XR), which are tributaries of the ZYS. A map of the study area is shown in Fig. 1. These rivers are mainly subject to continuous point-source inputs of pollutants in domestic and industrial wastewater effluents, and these sources have caused the water quality to deteriorate and the sediment in the rivers to become polluted. A field investigation revealed that the dominant sources of pollutants are tannery wastewater effluents to the SR and pharmaceutical wastewater effluents to the WR. Sewage and industrial wastewater effluents are significant sources of pollutants to the XR. The $\mathrm{SR}, \mathrm{WR}$, and $\mathrm{XR}$ receive 28,30 , and $290 \mathrm{Mm}^{3} / \mathrm{a}$ of wastewater effluents, respectively, each year.

\section{Sample collection and analysis}

Samples were collected at one sampling station on each of the SR, WR, and XR. The locations of the sampling sites are shown in Fig. 1. Three groups of sediment columns were taken at random from each station, and three cores of undisturbed sediment were collected in each group using a hand-held polyvinyl chloride corer with a diameter of $8 \mathrm{~cm}$ and a length of $60 \mathrm{~cm}$. Sediment samples were collected in a manner designed to minimize any disturbance to the sediment-water interface (Kalnejais et al. 2015). The cores were collected with at least $15 \mathrm{~cm}$ of overlying water and $20 \mathrm{~cm}$ of sediment columns. The cores were stored in a $4{ }^{\circ} \mathrm{C}$ walk-in refrigerator and brought back to the laboratory as soon as possible after they had been collected.

In the laboratory, the overlying water samples were collected from $10 \mathrm{~cm}$ above the sediment-water interface at each sampling point (Azcue et al. 1996) using a syringe and a silicone tube that had been decontaminated by immersing it in nitric acid. The cores of every group were treated in one of three ways: one core from each sampling station was used to determine the vertical distribution of heavy metals. And, the top $10 \mathrm{~cm}$ of this core was divided into $1-\mathrm{cm}$ slices, and the remainder of the core was divided into $2-\mathrm{cm}$ slices. Another core from each sampling station was used to determine the diffusive fluxes of heavy metals, and the top $5 \mathrm{~cm}$ of this core was divided into $0.5-\mathrm{cm}$ slices, and the remainder of the core was divided into 1-cm slices. The third core from each sampling station was used to determine the toxicity of the surface sediment, and the top $5 \mathrm{~cm}$ of the sediment core was taken as whole to extract pore water. All sub-samples of the sediments were centrifuged at $4000 \mathrm{rpm}$ for $30 \mathrm{~min}$ to separate pore water. Each overlying water and pore water sample was filtered through a cellulose membrane containing $0.45-\mu \mathrm{m}$ pores, preserved by adding ultrapure nitric acid, and stored at $4{ }^{\circ} \mathrm{C}$ until heavy metal analysis.

The concentrations of $\mathrm{Cd}, \mathrm{Cr}, \mathrm{Cu}, \mathrm{Ni}, \mathrm{Pb}, \mathrm{Zn}, \mathrm{Ca}$, and $\mathrm{Mg}$ were measured by inductively coupled plasma-mass 
Fig. 1 Map of the of the study area in the Ziya River system, with the sediment sampling sites indicated on the Shaocun River, Wangyang River, and Xiao River

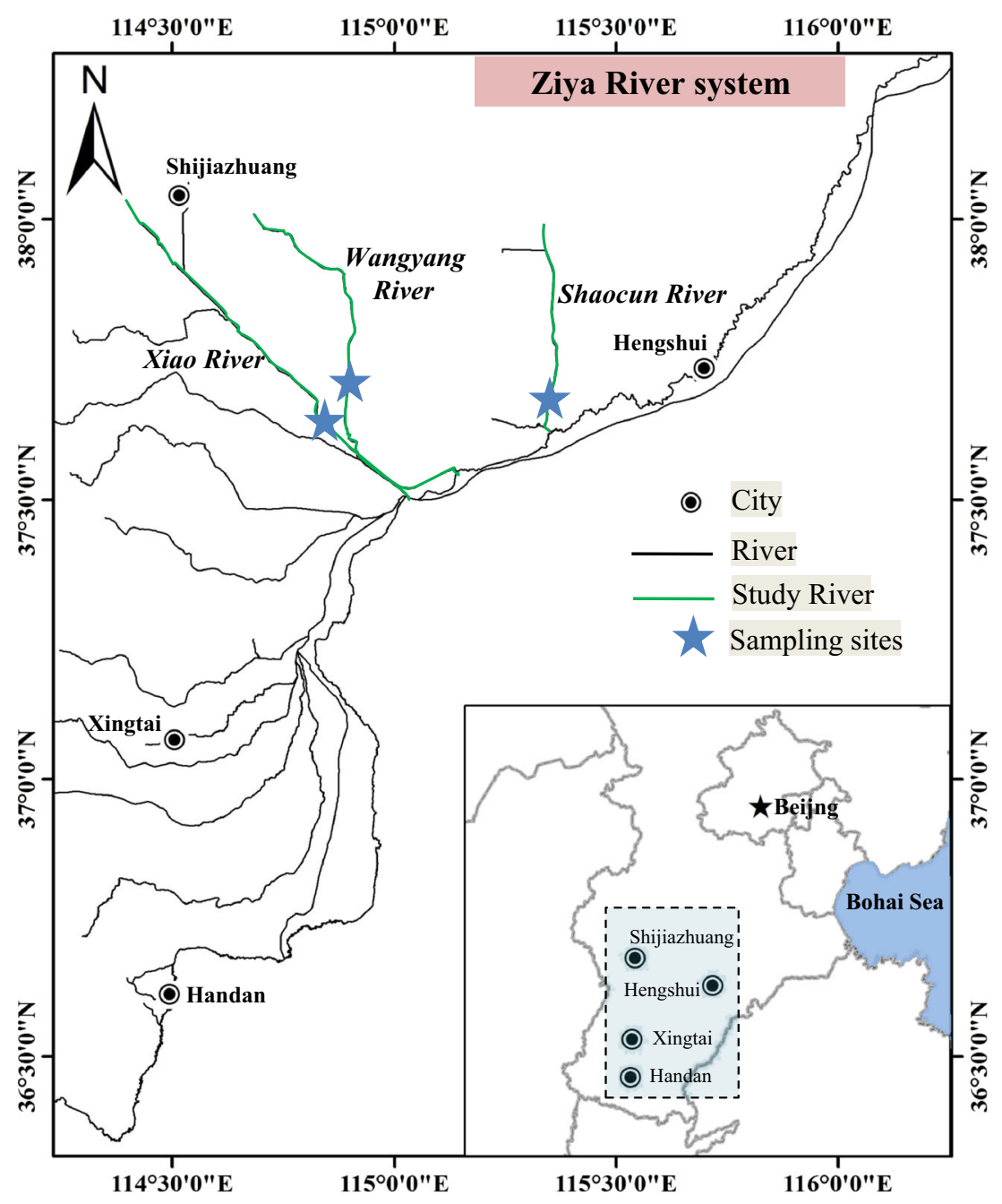

spectrometry (ICP-MS) (7500a, Agilent, USA) (detection limit $0.015-0.120 \mu \mathrm{g} / \mathrm{L}$ ) and inductively coupled plasma optical emission spectrometer (ICP-OES) (Optima 2000DV, PerkinElmer, USA) (detection limit $0.001-0.030 \mathrm{mg} / \mathrm{L}$ ). Laboratory quality control consisted of the analysis of black and triplicate samples. The precision of the method was acceptable (the relative standard deviation was $<5 \%$ ). The results of all indices were the average of the three parallel samples of pore water and overlying water, respectively.

\section{Diffusive fluxes}

The diffusive fluxes of the trace elements from the sediment to the water column were calculated from the concentration gradients found in the pore water samples using Fick's first law of diffusion (Berner 1984):

$F=\phi \cdot D_{S} \bullet\left(\frac{\partial C}{\partial \mathrm{x}}\right)_{x=0}$ where $F$ is the diffusive flux, $\varphi$ is the porosity of the sediment-water interface, $D_{S}$ is the molecular diffusion coefficient, and $\left(\frac{\partial C}{\partial x}\right)_{x=0}$ is the concentration gradient found at the sediment-water interface. The $D_{S}$ is calculated from the empirical equations (Ullman and Sandstrom 1987):

$D_{S}=\phi D_{0}(\phi<0.7)$

$D_{S}=\phi^{2} D_{0}(\phi>0.7)$

where $D_{0}$ is the diffusion coefficient in water. The values for $D_{0}$ for each metal are taken from Li and Gregory (1974). The concentration gradient was estimated from the pore water profiles, with the assumption that the gradient across the sediment-water interface is one-dimensional and can be approximated as the linear fitting slope of the 
concentration of metal in the sediment-water interface (Kalnejais et al. 2015, Sherman et al. 1994).

\section{Pore water toxicity analysis}

The interstitial water quality was examined for each metal using a water quality index, the interstitial water criteria toxicity unit (IWCTU), defined as:

$I W C T U_{M e}=\frac{[M e]_{i, w .}}{F C V_{M e}}$,

where $[M e]_{\text {i.w. }}$ is the dissolved metal $(\mathrm{Me})$ concentration and $F C V_{M e}$ is the hardness-dependent final chronic value for the metal (Lourino-Cabana et al. 2011, Sterckeman et al. 2000). While the $\mathrm{I} W C T U_{M e}$ exceeds 1, it implies that there is a risk of toxicity to aquatic organism. The method for calculating $F C V_{M e}$ is presented in Table 1 (EPA. 2002).

The Nemeraw index (NI) was also used to estimate the pore water quality, and it was calculated as shown in Eq. 4:

$(N I)=\sqrt{\frac{(I W C T U)_{\max }^{2}+(I W C T U)_{\text {mean }}^{2}}{2}}$.

Five grades of toxic impact were used: no impact, slight impact, moderate impact, strong impact, and serious impact, with NI values of $<1,1-2,2-3,3-5$, and $>5$, respectively (Liu et al. 2003).

\section{Statistical analysis}

The data were analyzed using SPSS 19.0 for Windows software. Pearson correlation coefficients were used to assess the relationships between the heavy metal concentrations in the pore water. Origin Pro 8.0 software was used to plot the data. One-sample $t$ tests $(p \leq 0.05)$ were used to assess the differences between groups of data. All of the results used were averages of the results found from analyzing three parallel sediment core samples.

Table 1 Final chronic values (FCVs) for the metals based on the dissolved metal concentration

\begin{tabular}{ll}
\hline Metal & FCV \\
\hline $\mathrm{Cd}$ & {$[1.101672-0.041838 \ln ($ hardness $)]\left[\mathrm{e}^{0.7852 \ln (\text { hardness })-3.490}\right]$} \\
$\mathrm{Cu}$ & $0.960\left[\mathrm{e}^{0.8545 \ln (\text { hardness })-1.465}\right]$ \\
$\mathrm{Ni}$ & $0.997\left[\mathrm{e}^{0.8460 \ln (\text { hardness })+1.1645}\right]$ \\
$\mathrm{Pb}$ & $0.791\left[\mathrm{e}^{1.273 \ln \text { (hardness) }-4.705}\right]$ \\
$\mathrm{Zn}$ & $0.986\left[\mathrm{e}^{0.8473 \ln \text { (hardness) }+0.7614}\right]$ \\
\hline
\end{tabular}

\section{Results and discussion}

\section{Spatial and vertical distributions of the heavy metals in the pore water}

The $\mathrm{Cd}, \mathrm{Cr}, \mathrm{Cu}, \mathrm{Ni}, \mathrm{Pb}$, and $\mathrm{Zn}$ concentrations in the pore water samples from the SR, WR, and XR varied both spatially and vertically, as shown in Fig. 2. The metals followed different spatial and vertical distribution trends from each other and at the different sites because different types of wastewater contain different mixtures of metals and other pollutants. The mean concentrations were gained by averaging the values of heavy metal in all depths. And, the mean $\mathrm{Cd}, \mathrm{Cr}, \mathrm{Cu}, \mathrm{Ni}$, $\mathrm{Pb}$, and $\mathrm{Zn}$ concentrations in all three tributaries were 0.373 , $57.1,37.7,20.4,14.0$, and $90.6 \mu \mathrm{g} / \mathrm{L}$, respectively.

In terms of the spatial variability, the results showed that the pore water in the SR samples contained high mean concentrations of $\mathrm{Pb}(17.1 \mu \mathrm{g} / \mathrm{L})$ and $\mathrm{Zn}(105 \mu \mathrm{g} / \mathrm{L})$, whereas the pore water in the WR samples contained high mean concentrations of $\mathrm{Cd}(0.488 \mu \mathrm{g} / \mathrm{L}), \mathrm{Cr}(78.3 \mu \mathrm{g} / \mathrm{L}), \mathrm{Cu}(50.8 \mu \mathrm{g} / \mathrm{L})$, and $\mathrm{Ni}(23.2 \mu \mathrm{g} / \mathrm{L})$. The metal concentrations in the pore water decreased in the order $\mathrm{Zn}>\mathrm{Cr}>\mathrm{Cu}>\mathrm{Ni}>\mathrm{Pb}>\mathrm{Cd}$ in the samples from the $\mathrm{XR}$ and the WR, but in the order $\mathrm{Zn}>\mathrm{Cu}>\mathrm{Cr}>\mathrm{Pb}>\mathrm{Ni}>\mathrm{Cd}$ in the samples from the SR. It can be assumed that the metal concentrations in all three tributaries were predominantly controlled by the metals being released in contaminated wastewater in the ZYS area, which suffers from a severe shortage of water. The main sources of water to the SR, WR, and XR are sewage and other wastewater discharges, and different types of wastewater will supply different patterns of trace metal pollution and result in different trace metal patterns in sediment (Tang et al. 2015).

In terms of the vertical variability, the concentrations of $\mathrm{Cd}$, $\mathrm{Cr}, \mathrm{Pb}$, and $\mathrm{Zn}$ in the $\mathrm{XR}$ pore water generally increased with depth increased and reached a maximum at 8 to $15-\mathrm{cm}$ depth and then decreased, except for the $\mathrm{Cu}$ concentrations, which decreased as the depth increased. The $\mathrm{Cr}, \mathrm{Cu}$, and $\mathrm{Ni}$ concentration maxima in the WR pore water were found at $15-\mathrm{cm}$ depth, and the $\mathrm{Cd}, \mathrm{Pb}$, and $\mathrm{Zn}$ concentration maxima were found at $10-\mathrm{cm}$ depth. The concentrations of most of the metals in the SR pore water varied slightly, and the highest concentration was founded between 15- and 20-cm depth, except for $\mathrm{Zn}$, which concentration was varied dramatically in all depths. Most of the metals were found at low concentrations in the top layers of the sediment (which correspond with the oxic zone), and higher metal concentrations were found in the deeper layers corresponding with the sub-oxic zones, and these results were similar to the results of other studies (Campanha et al. 2012, Couture et al. 2010, SantosEcheandia et al. 2009).

Fig. 2 Spatial-vertical distributions of metals concentrations in the pore water sediments samples from XR (a), WR (b), and SR (c) 


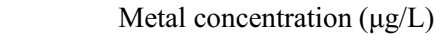

Metal concentration $(\mu \mathrm{g} / \mathrm{L})$

Metal concentration $(\mu \mathrm{g} / \mathrm{L})$
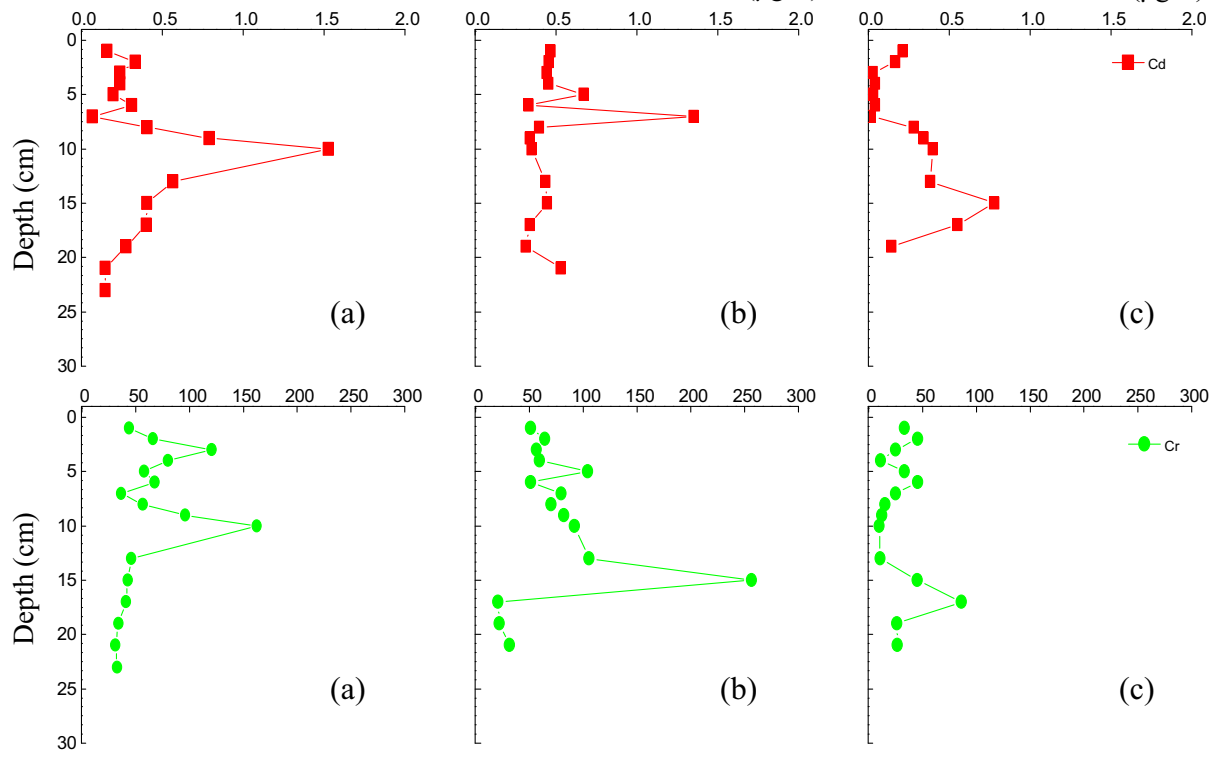

(c)
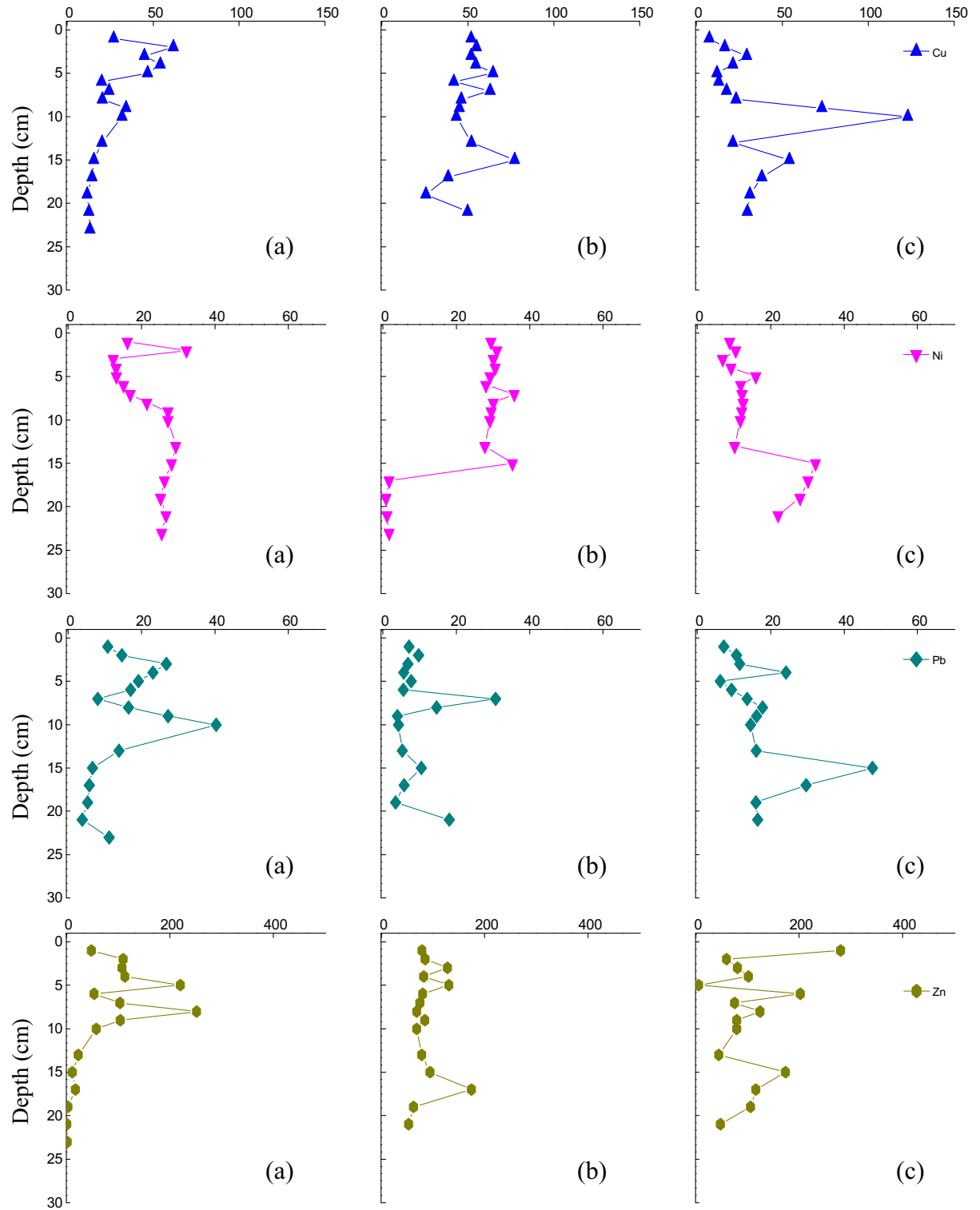
Table $2 \mathrm{Cd}, \mathrm{Cr}, \mathrm{Cu}, \mathrm{Ni}, \mathrm{Pb}$, and $\mathrm{Zn}$ concentrations in sediment pore water from the Xiao River, the Wangyang River, and the Shaocun River and other water bodies in China and other regions

\begin{tabular}{|c|c|c|c|c|c|c|c|}
\hline \multirow[t]{2}{*}{ Site } & \multicolumn{6}{|c|}{ Maximum concentration $(\mu \mathrm{g} / \mathrm{L})$} & \multirow[t]{2}{*}{ Reference } \\
\hline & $\mathrm{Cd}$ & $\mathrm{Cr}$ & $\mathrm{Cu}$ & $\mathrm{Ni}$ & $\mathrm{Pb}$ & $\mathrm{Zn}$ & \\
\hline Xiao River, China & 1.53 & 162 & 61.8 & 32.2 & 40.3 & 252 & This study \\
\hline Wangyang River, China & 1.35 & 257 & 77.3 & 35.9 & 30.8 & 174 & This study \\
\hline Shaocun River, China & 0.779 & 86.2 & 123.1 & 32.2 & 47.8 & 281 & This study \\
\hline Xiangjiang River, China & 16.7 & & 43.9 & & 74.5 & 417 & Han et al. (2013) \\
\hline Liao River, China & 0.9 & & 5.7 & & 2.22 & 59.5 & Deng BL (2011) \\
\hline Songhua River, China & & & 154 & 167 & 357 & 56 & Zhu et al. (2011) \\
\hline Liao River, China & 1.24 & 30.1 & 17 & 10.3 & 18.2 & 27.8 & Bu et al. (2014) \\
\hline Delûe River, France & 7 & & 16.5 & 11.9 & 115.6 & 112.1 & Lourino-Cabana et al. (2011) \\
\hline $\begin{array}{l}\text { Meuse River, } \\
\text { The Netherlands }\end{array}$ & 0.135 & & 5.597 & 12.74 & 6.84 & 27.73 & Van Den Berg et al. (1999) \\
\hline Tagus estuary, Portugal & 6.5 & & 10.7 & & 28.5 & 915 & Santos-Echeandía et al. (2010) \\
\hline Dose Lake, USA & 0.9 & 13 & 2 & 38.2 & 14.9 & & Balistrieri et al. (2003) \\
\hline river Leie, Belgian & 0.16 & & 3 & 8.7 & 1.3 & 46 & Gao et al. (2006) \\
\hline Great Salt Lake, USA & & 3.3 & 50.7 & 22.1 & 1.8 & & Carling et al. (2013) \\
\hline
\end{tabular}

The trace metal concentrations found in the present study were compared with those determined in other areas (Table 2). It can be observed that the concentrations of most metals in the ZYS were higher than the contents in other regions. The concentrations of the trace metals, particularly $\mathrm{Cr}$ and $\mathrm{Zn}$, were higher in the ZYS samples than what have been found in other Chinese riverine sediment pore water samples. The $\mathrm{Cu}, \mathrm{Ni}$, and Zn concentrations were higher in ZYS pore water than in pore water from rivers in other parts of the world, whereas the $\mathrm{Cd}$ and $\mathrm{Pb}$ concentrations were lower in ZYS pore water than in pore water from rivers in other parts of the world. The high concentrations of metals in pore water indicated that as a region with industrial development and rapid urbanization, the ZYS has been polluted by artificial activities.

\section{Relationships between the heavy metal concentrations}

A high correlation coefficient for the relationship between two metals means that they are likely to share common sources (Suresh et al. 2011). The relationships between the heavy metal concentrations in the pore water samples were analyzed using the Pearson correlation coefficients (see Table 3). For the XR samples, the $\mathrm{Pb}$ concentrations correlated well with the concentrations of $\mathrm{Cd}(r=0.713, p<0.01), \mathrm{Cr}(r=0.952, p<0.01)$, and $\mathrm{Cu}(r=0.544, p<0.05)$, and the $\mathrm{Cr}$ and $\mathrm{Cd}$ concentrations also correlated well $(r=0.745, p<0.01)$. The $\mathrm{Ni}$ concentrations did not correlate well with the concentrations of any of the other metals in the XR samples. In the WR samples, significant positive correlations $(p<0.01)$ were found between the $\mathrm{Cd}$ and $\mathrm{Pb}$ concentrations, and good

Table 3 Pearson correlation coefficients for the relationships between the concentrations of the metals analyzed in samples from the Xiao River, the Wangyang River, and the Shaocun River

\begin{tabular}{llllll}
\hline Site & $\mathrm{Cd}$ & $\mathrm{Cr}$ & $\mathrm{Cu}$ & $\mathrm{Ni}$ & $\mathrm{Pb}$ \\
\hline Xiao River & & & & & \\
$\mathrm{Cr}$ & $0.745^{\mathrm{a}}$ & & & & \\
$\mathrm{Cu}$ & 0.051 & 0.493 & & & \\
$\mathrm{Ni}$ & 0.412 & -0.117 & -0.283 & & \\
$\mathrm{~Pb}$ & $0.713^{\mathrm{a}}$ & $0.952^{\mathrm{a}}$ & $0.544^{\mathrm{b}}$ & -0.186 & \\
$\mathrm{Zn}$ & -0.034 & 0.230 & $0.541^{\mathrm{b}}$ & -0.439 & 0.381 \\
$\mathrm{Wangyang}$ River & & & & & \\
$\mathrm{Cr}$ & 0.092 & & & & \\
$\mathrm{Cu}$ & 0.496 & $0.759^{\mathrm{a}}$ & & & \\
$\mathrm{Ni}$ & 0.302 & $0.551^{\mathrm{b}}$ & $0.637^{\mathrm{b}}$ & & \\
$\mathrm{Pb}$ & $0.860^{\mathrm{a}}$ & 0.064 & 0.418 & 0.139 & \\
$\mathrm{Zn}$ & -0.076 & -0.010 & 0.097 & -0.110 & -0.248 \\
$\mathrm{Shaocun} \mathrm{River}$ & & & & & \\
$\mathrm{Cr}$ & 0.300 & & & & \\
$\mathrm{Cu}$ & 0.500 & -0.229 & & & \\
$\mathrm{Ni}$ & $0.607^{\mathrm{b}}$ & $0.563^{\mathrm{b}}$ & 0.136 & & \\
$\mathrm{~Pb}$ & $0.780^{\mathrm{a}}$ & 0.300 & 0.270 & $0.687^{\mathrm{a}}$ & \\
$\mathrm{Zn}$ & 0.182 & 0.262 & -0.143 & 0.048 & 0.153 \\
\hline $\mathrm{C}$ & & & & & \\
\hline
\end{tabular}

${ }^{\text {a }}$ Correlation significant at the 0.01 level (2-tailed)

${ }^{\mathrm{b}}$ Correlation significant at the 0.05 level (2-tailed) 
Fig. 3 Fluxes of dissolved metals at the sediment-water interface in the three water bodies of the ZYS

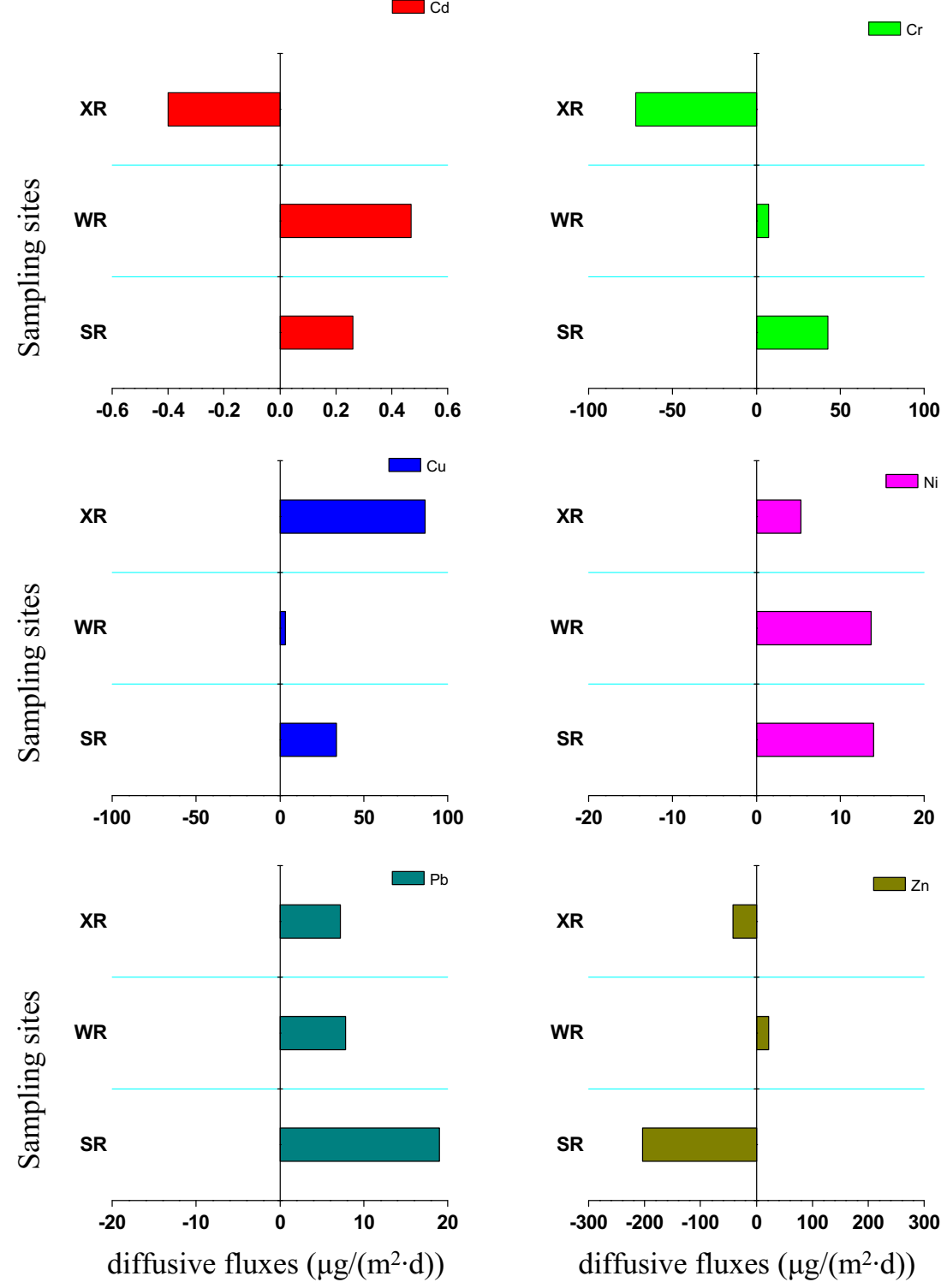

positive correlations were also found between the $\mathrm{Cr}, \mathrm{Cu}$, and $\mathrm{Ni}$ concentrations. The $\mathrm{Cd}, \mathrm{Ni}$, and $\mathrm{Pb}$ concentrations in the SR samples positively correlated, indicating that the spatial distributions of these metals were controlled by common local inputs and similar dispersion processes at the SR sampling site. No correlations were found between the concentrations of $\mathrm{Zn}$ and the other metals in the SR samples, suggesting that Zn contamination in the SR might have different origins from contamination with the other metals.

The significant positive correlations of $\mathrm{Cd}, \mathrm{Cr}$, and $\mathrm{Pb}$ in XR may be interpreted as the high enrichment factor (EF) values of these three metals in XR sediments, which indicated that the three metals in the sediments had anthropogenic origins (Tang et al. 2015). Moreover, the $\mathrm{Cd}, \mathrm{Cr}$, and $\mathrm{Pb}$ in the sediments of XR may come from similar sources (domestic sewage and industrial wastewater) (Tang et al. 2015). However, hydrodynamics, biogeochemical progress, and environmental conditions also influenced the partitioning behavior and distribution of metals between pore water and solid phase in the sediments (Eggleton and Thomas, 2004). In addition, the $\mathrm{Cd}$ and $\mathrm{Pb}$ concentrations significantly positively correlated in all three tributaries $(p<0.01)$, which may be because that they are both typical anthropogenic metals, and human activities control their concentrations in the sediments of the ZYS (Quinton and Catt 2007).

\section{Diffusive fluxes of the heavy metals from the pore water to the overlying water}

The diffusive fluxes from the sediment pore water to the overlying water were calculated to estimate the risks of 
Table 4 Fluxes of dissolved metals in the three rivers in the Ziya River system that were studied: the Xiao River, the Wangyang River, and the Shaocun River; and in rivers in other regions

\begin{tabular}{|c|c|c|c|c|c|c|c|}
\hline & \multicolumn{6}{|c|}{ Fluxes of dissolved metals $\left(\mu \mathrm{g} /\left(\mathrm{m}^{2} \cdot \mathrm{d}\right)\right)$} & \multirow[t]{2}{*}{ Reference } \\
\hline & $\mathrm{Cd}$ & $\mathrm{Cr}$ & $\mathrm{Cu}$ & $\mathrm{Ni}$ & $\mathrm{Pb}$ & $\mathrm{Zn}$ & \\
\hline Xiao River & -0.427 & -71.8 & 86.6 & 5.29 & 7.24 & -41.4 & This study \\
\hline Wangyang River & 0.469 & 7.39 & 3.16 & 13.7 & 7.86 & 21.9 & This study \\
\hline Shaocun River & 0.258 & 42.5 & 33.6 & 14.0 & 19.0 & -204 & This study \\
\hline Meuse River, The Netherlands & 0.038 & & & 3.656 & -5.5 & 7.60 & Van Den Berg et al. (1999) \\
\hline Deule River, northern France & 6.04 & & 12.0 & -0.45 & & 64.7 & Lourino-Cabana et al. (2012) \\
\hline Rupel River, Belgium & 0.3 & & 5 & 10 & & 372 & Leermakers et al. (2005) \\
\hline Scheldt River, France and Belgium & 2.00 & & 9.53 & 15.48 & 27.25 & 138.8 & Gao et al. (2006) \\
\hline Bang Pakong River, Thailand & 0.3 & 0.2 & 58 & 2.7 & 4.0 & 41 & Cheevaporn et al. (1995) \\
\hline Elbe River, Germany & 0.8 & 0.4 & 131 & 27.5 & 6.81 & 63 & Petersen et al. (1995) \\
\hline Odiel River, Spain & & 0 & 483 & 580 & & 9810 & Blasco et al. (2000) \\
\hline Caper, Brazil & & 0 & 35 & & & & Campanha et al. (2012) \\
\hline Rturarg, Brazil & & 0 & 6302 & & & & Campanha et al. (2012) \\
\hline Rgrande, Brazil & & 0.5 & 0.2 & 0.3 & -3.491 & & Campanha et al. (2012) \\
\hline
\end{tabular}

heavy metals being released from the river sediment. The top $5 \mathrm{~cm}$ of sediment cores were divided into $0.5-\mathrm{cm}$ slices, and the remainder of the core was divided into $1-\mathrm{cm}$ slices to obtain the concentration profiles at the sediment-water interface. The diffusive fluxes are shown in Fig. 3. All of the metals in the WR were found to diffuse from the sediment to the overlying water, and $\mathrm{Cu}$ was found to have the highest diffusive flux from the sediment to the overlying water in all three tributaries. The mean diffusive fluxes of $\mathrm{Cd}, \mathrm{Cr}, \mathrm{Cu}, \mathrm{Ni}, \mathrm{Pb}$, and $\mathrm{Zn}$ in the SR were $0.258,42.5,33.6,14.0,19.0$, and $-204 \mu \mathrm{g} /\left(\mathrm{m}^{2}\right.$ day $)$, respectively, meaning that the net $\mathrm{Cu}, \mathrm{Cr}, \mathrm{Cd}, \mathrm{Pb}$, and $\mathrm{Ni}$ fluxes were from the pore water to the overlying water and that the net $\mathrm{Zn}$ flux was from the overlying water to the sediment. The mean diffusive fluxes of $\mathrm{Cd}, \mathrm{Cr}, \mathrm{Cu}, \mathrm{Ni}, \mathrm{Pb}$, and $\mathrm{Zn}$ in the $\mathrm{WR}$ were $0.469,7.39,3.16,13.7,7.86$, and $21.9 \mu \mathrm{g} /\left(\mathrm{m}^{2}\right.$ day $)$, respectively, meaning that the net fluxes of all six metals were from the pore water to the overlying water. The mean diffusive fluxes of $\mathrm{Cd}, \mathrm{Cr}, \mathrm{Cu}, \mathrm{Ni}, \mathrm{Pb}$, and $\mathrm{Zn}$ in the XR were $-0.427,-71.8,86.6,5.29,7.24$, and $-41.4 \mu \mathrm{g} /\left(\mathrm{m}^{2}\right.$ day $)$, respectively, meaning that the net $\mathrm{Cd}, \mathrm{Cr}$, and $\mathrm{Zn}$ fluxes were from the pore water to the overlying water.

We found that $\mathrm{Cu}, \mathrm{Ni}$, and $\mathrm{Pb}$ were being released to the overlying water in all of the rivers studied, so they may negatively affect surface water quality and pose health risks. Heavy metals in pore water in the WR were found to pose the greatest ecological risk, and all of the metals had diffusion rates of $>0$, probably because the highest concentrations of most of the heavy metals were found in the WR pore water samples. The release fluxes of some of the heavy metals, especially $\mathrm{Cr}$, in the SR were very high, even though the SR pore water samples did not contain the highest concentrations. The results indicated that the sediments have become important pollution sources of heavy metals in the SR due to the discharge of leather industry wastewater in recent decades (Tang et al. 2015).

The fluxes found in our study are compared with fluxes found in other places in Table 4. The fluxes we found were generally close to those found in other polluted rivers around the world, including the Meuse River in the Netherlands (Van Den Berg et al. 1999), the Deule River in France (Lourino-Cabana et al. 2012), and the Bang Pakong River in Thailand (Cheevaporn et al. 1995). Flux calculations can suffer serious errors because of the presence of hydroxides and oxides and the occurrence of bioturbation, bioirrigation, and resuspension caused by wave action and shipping activities (Van Den Berg et al. 1999). Therefore, the actual net diffusion of

Table 5 Hardness-dependent final chronic value (FCVMe) determined for $\mathrm{Cd}, \mathrm{Cu}, \mathrm{Ni}, \mathrm{Pb}$ and $\mathrm{Zn}$ in pore water of the Xiao River (XR), the Wangyang River (WR), and the Shaocun River (SR)

\begin{tabular}{lllllll}
\hline River & $\mathrm{CaCO}_{3}(\mathrm{mg} / \mathrm{L})$ & $\mathrm{FCV}_{\mathrm{Cd}}$ & $\mathrm{FCV}_{\mathrm{Cu}}$ & $\mathrm{FCV}_{\mathrm{Ni}}$ & $\mathrm{FCV}_{\mathrm{Pb}}$ & $\mathrm{FCV}_{\mathrm{Zn}}$ \\
\hline $\mathrm{XR}$ & 396 & 2.85 & 36.7 & 503 & 14.5 & 335 \\
$\mathrm{WR}$ & 376 & 2.74 & 35.2 & 482 & 13.5 & 321 \\
$\mathrm{SR}$ & 296 & 2.30 & 28.7 & 394 & 10.0 & 262 \\
\hline
\end{tabular}


Table 6 Toxic unit analysis results for the dissolved metals in sediment in the three rivers in the Ziya River system that were studied: the Xiao River (XR), the Wangyang River (WR), and the Shaocun River (SR)

\begin{tabular}{|c|c|c|c|c|c|c|c|c|c|c|c|c|c|}
\hline \multirow[t]{2}{*}{ River } & \multicolumn{2}{|l|}{$\mathrm{Cd}$} & \multicolumn{2}{|l|}{$\mathrm{Cu}$} & \multicolumn{2}{|l|}{$\mathrm{Ni}$} & \multicolumn{2}{|l|}{$\mathrm{Pb}$} & \multicolumn{2}{|l|}{$\mathrm{Zn}$} & \multirow[t]{2}{*}{ 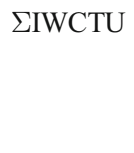 } & \multirow[t]{2}{*}{ NI } & \multirow{2}{*}{$\begin{array}{l}\text { Impact } \\
\text { grade }\end{array}$} \\
\hline & $\begin{array}{l}\mathrm{Cd} \\
(\mu \mathrm{g} / \mathrm{L})\end{array}$ & $\mathrm{IWCTU}_{\mathrm{Cd}}$ & $\begin{array}{l}\mathrm{Cu} \\
(\mu \mathrm{g} / \mathrm{L})\end{array}$ & IWCTU $_{\mathrm{Cu}}$ & $\begin{array}{l}\mathrm{Ni} \\
(\mu \mathrm{g} / \mathrm{L})\end{array}$ & $\operatorname{IWCTU}_{\mathrm{Ni}}$ & $\begin{array}{l}\mathrm{Pb} \\
(\mu \mathrm{g} / \mathrm{L})\end{array}$ & IWCTU $_{\mathrm{Pb}}$ & $\begin{array}{l}\mathrm{Zn} \\
(\mu \mathrm{g} / \mathrm{L})\end{array}$ & $\mathrm{IWCTU}_{\mathrm{Zn}}$ & & & \\
\hline & $\begin{array}{l}\mathrm{Cd} \\
\quad(\mu \mathrm{g} / \mathrm{L})\end{array}$ & IWCTU $_{\mathrm{Cd}}$ & $\begin{array}{l}\mathrm{Cu} \\
\quad(\mu \mathrm{g} / \mathrm{L})\end{array}$ & $\mathrm{IWCTU}_{\mathrm{Cu}}$ & $\begin{array}{l}\mathrm{Ni} \\
\quad(\mu \mathrm{g} / \mathrm{L})\end{array}$ & $\mathrm{IWCTU}_{\mathrm{Ni}}$ & $\begin{array}{l}\mathrm{Pb} \\
\quad(\mu \mathrm{g} / \mathrm{L})\end{array}$ & IWCTU $_{\mathrm{Pb}}$ & $\begin{array}{l}\mathrm{Zn} \\
\quad(\mu \mathrm{g} / \mathrm{L})\end{array}$ & $\mathrm{IWCTU}_{\mathrm{Zn}}$ & & & \\
\hline $\mathrm{XR}$ & 0.207 & 0.073 & 41.2 & 1.12 & 20.1 & 0.040 & 15.6 & 1.07 & 83.2 & 0.248 & 2.55 & 0.870 & NO \\
\hline WR & 0.430 & 0.157 & 49.5 & 1.41 & 28.6 & 0.059 & 7.37 & 0.542 & 88.0 & 0.274 & 2.52 & 1.05 & Slight \\
\hline SR & 0.074 & 0.032 & 16.6 & 0.579 & 8.6 & 0.022 & 9.97 & 0.993 & 109 & 0.415 & 2.87 & 0.759 & $\mathrm{NO}$ \\
\hline
\end{tabular}

Data in bold when violating the corresponding water quality criteria recommended by EPA (2002)

each metal from the sediment to the dissolved phase in the surface water is probably much lower than that reported in Table 4.

\section{Toxic unit analysis of the pore water}

The dissolved phase concentration of a contaminant in interstitial water in sediment reflects the contaminant's activity and is a good surrogate for the bioavailable concentration (Burgess et al. 2013). It has previously been observed in several studies (Gaillard et al. 1986, Lourino-Cabana et al. 2011) that metal concentrations in pore water reach maxima in the surficial sediment layers $(\sim 1-3 \mathrm{~cm}$ deep). The surface sediment $(0-5 \mathrm{~cm})$ interstitial water was collected from samples from the rivers that were studied and analyzed so that the metal toxicities in the XR, WR, and SR could be estimated.

The FCV values of the selected metals $(\mathrm{Cd}, \mathrm{Cu}, \mathrm{Ni}$, $\mathrm{Pb}$, and $\mathrm{Zn}$ ) were determined (Table 5), and the IWCTU index was calculated from Eq. (3) for each metal at every site. We found that the IWCTU values for $\mathrm{Cu}$ and $\mathrm{Pb}$ in the surface sediment in the rivers that were studied exceeded the appropriate water quality criteria recommended by the US Environmental Protection Agency (Table 6). The IWCTU $\mathrm{Iu}_{\mathrm{Cu}}$ values for the XR and WR were $>1$, as was the $\operatorname{IWCTU}_{\mathrm{Pb}}$ value for the $\mathrm{XR}$. Two indices, the total IWCTU and the NI, both combining the results for multiple metals, were used to estimate the pore water quality. The total IWCTU and NI values showed that the interstitial water was not seriously contaminated with the metals studied in any of the three rivers, but a high NI value, slightly higher than 1, was found for the WR sediment, showing that the heavy metals in the WR sediment pose risks of inducing toxic effects.

These findings were not the same as the potential ecological risk (PER) of sediments. Previous research (Tang et al. 2015) has reported that $\mathrm{Cd}$ in the sediments of XR showed serious PER, and $\mathrm{Pb}$ in WR showed higher PER.
The difference indicated that it was not accurate to estimate the sediment quality only depending on the chemical composition of sediments. Bioavailability and speciation of metals in the sediments should be considered. The previous results showed that the toxicity of pore water corresponded well to sediment toxicity (SchubauerBerigan and Ankley 1991). The metal toxicity in sediments is directly related to the concentration in pore water, which is also influenced by the characteristics of sediments and pore water, such as $\mathrm{pH}$, hardness, acid volatile sulfide (AVS), and organic matter (OM) (Crommentuijn et al. 1997). Therefore, it should be known that bioassay is very necessary to comprehensively assess heavy metal contamination in the sediments of aquatic ecosystem in future studies.

\section{Conclusions}

The distributions, fluxes, and toxicities of $\mathrm{Cd}, \mathrm{Cr}, \mathrm{Cu}$, $\mathrm{Ni}, \mathrm{Pb}$, and $\mathrm{Zn}$ in sediment pore water were investigated in three tributaries of the ZRS with different wastewater sources. The mean $\mathrm{Cd}, \mathrm{Cr}, \mathrm{Cu}$, and $\mathrm{Ni}$ concentrations in the pore water were higher in samples from the WR, which receives pharmaceutical wastewater discharges, than in the samples from the XR and SR. The diffusive fluxes indicated that sediments in the WR and SR acted as sources of metals to the water columns in these rivers. The total IWCTU and NI values showed that the interstitial water was not seriously contaminated with the studied metals in any of the three rivers, which was inconsistent with the PER of sediments due to heavy metals. Therefore, bioassay will be very necessary to comprehensively assess heavy metal contamination in the sediments of aquatic ecosystem. The information provided by this study will be useful in identifying the metal pollution status of the rivers in the ZYS and in similar watersheds in northern China and would allow for effective management strategies to be developed. 
Acknowledgments This research was supported by the State Key Joint Laboratory of Environment Simulation and Pollution Control (Project No. 15L01ESPC) and the National Natural Science Foundation of China (No. 21107126).

\section{References}

Ankley GT, Phipps GL, Leonard EN, Benoit DA, Mattson VR, Kosian PA, Cotter AM, Dierkes JR, Hansen DJ, Mahony JD (1991) Acidvolatile sulfide as a factor mediating cadmium and nickel bioavailability in contaminated sediments. Environ Toxicol Chem 10:12991307

Azcue JM, Rosa F, Mudroch A (1996) Distribution of major and trace elements in sediments and pore water of Lake Erie. J Great Lakes Res 22:389-402

Balistrieri LS, Box SE, Tonkin JW (2003) Modeling precipitation and sorption of elements during mixing of river water and porewater in the Coeur d'Alene River basin. Environ Sci Technol 37:4694-4701

Berner RA (1984) Sedimentary pyrite formation: an update. Geochim Cosmochim 48:605-615

Blasco J, Sáenz V, Gómez-Parra A (2000) Heavy metal fluxes at the sediment-water interface of three coastal ecosystems from southwest of the Iberian Peninsula. Sci Total Environ 247:189-199

Bu J, Chen H, Xu Y, Zha J, Wang Z (2014) Ecological risk of interstitial water heavy metals and toxicity characterization of surface sediments in branches of Liaohe River. Asian J Ecotox 9:24-34 (in Chinese)

Burgess RM, Berry WJ, Mount DR, Di Toro DM (2013) Mechanistic sediment quality guidelines based on contaminant bioavailability: equilibrium partitioning sediment benchmarks. Environ Toxicol Chem 32:102-114

Campanha MB, Moreira AB, Bisinoti MC (2012) Metal fluxes at the sediment-water interface in rivers in the Turvo/Grande drainage basin, São Paulo State, Brazil. J Soil Sediment 12: $1508-1516$

Carling GT, Richards DC, Hoven H, Miller T, Fernandez DP, Rudd A, Pazmino E, Johnson WP (2013) Relationships of surface water, pore water, and sediment chemistry in wetlands adjacent to Great Salt Lake, Utah, and potential impacts on plant community health. Sci Total Environ 443:798-811

Cheevaporn V, Jacinto G, San Diego-McGlone M (1995) Heavy metal fluxes in Bang Pakong River Estuary, Thailand: sedimentary vs diffusive fluxes. Mar Pollut Bull 31:290-294

Ciceri G, Maran C, Martinotti W, Queirazza G (1992) Geochemical cycling of heavy metals in a marine coastal area: benthic flux determination from pore water profiles and in situ measurements using benthic chambers. Hydrobiologia 235:501-517

Cortecci G, Boschetti T, Dinelli E, Cidu R, Podda F, Doveri M (2009) Geochemistry of trace elements in surface waters of the Arno River Basin, northern Tuscany, Italy. Appl Geochem 24:1005-1022

Costello DM, Hammerschmidt CR, Burton GA (2015) Copper sediment toxicity and partitioning during oxidation in a flow-through flume. Environ Sci Technol 49:6926-6933

Couture RM, Gobeil C, Tessier A (2010) Arsenic, iron and sulfur codiagenesis in lake sediments. Geochim Cosmochim 74:1238-1255

Crommentuijn T, Doornekamp A, Van Gestel C (1997) Bioavailability and ecological effects of cadmium on Folsomia candida (Willem) in an artificial soil substrate as influenced by $\mathrm{pH}$ and organic matter. Appl Soil Ecol 5:261-271

Davis A, Galloway JN (1993) Distribution of Pb between sediments and pore water in Woods Lake, Adirondack State Park, New York, USA. Appl Geochem 8:51-65
Deng BL, Zhu L, Liu M, Liu NN, Yang LP, Du Y (2011) Sediment quality criteria and ecological risk assessment for heavy metals in Taihu Lake and Liao River. Res Environ Sci 24:33-42 (in Chinese)

Donahoe RJ, Liu CX (1998) Pore water geochemistry near the sedimentwater interface of a zoned, freshwater wetland in the southeastern United States. Environ Geol 33:143-153

Eggleton J, Thomas KV (2004) A review of factors affecting the release and bioavailability of contaminants during sediment disturbance events. Environ Int 30:973-980

EPA. US (2002) National recommended water quality criteria. Environmental Protection Agency Office of Water, Washington DC, US

Gaillard JF, Jeandel C, Michard G, Nicolas E, Renard D (1986) Interstitial water chemistry of Villefranche Bay sediments: trace metal diagenesis. Mar Chem 18:233-247

Gao Y, Leermakers M, Gabelle C, Divis P, Billon G, Ouddane B, Fischer J-C, Wartel M, Baeyens W (2006) High-resolution profiles of trace metals in the pore waters of riverine sediment assessed by DET and DGT. Sci Total Environ 362:266-277

Hall W (1996) Bioavailability of chromium, copper, and lead in estuarine wetland sediments. Proceedings of the 69th Water Environment Federation Technology Conference and Exposition, Dallas, TX, Surface Water and Ecology, vol. 4, Water Environment Federation, Alexandria, VA

Han CN, Qin YW, Zheng BH, Zhang L, Cao W (2013) Application of equilibrium partitioning approach to establish sediment quality criteria for heavy metals in Hengyang Section of Xiangjiang River. Environ Sci 34:1715-1724 (in Chinese)

Kalnejais LH, Martin WR, Bothner MH (2015) Porewater dynamics of silver, lead and copper in coastal sediments and implications for benthic metal fluxes. Sci Total Environ 517:178-194

Kucuksezgin F, Uluturhan E, Batki H (2008) Distribution of heavy metals in water, particulate matter and sediments of Gediz River (Eastern Aegean). Environ Monita Assess 141:213-225

Leermakers M, Gao Y, Gabelle C, Lojen S, Ouddane B, Wartel M, Baeyens W (2005) Determination of high resolution pore water profiles of trace metals in sediments of the Rupel River (Belgium) using DET (diffusive equilibrium in thin films) and DGT (diffusive gradients in thin films) techniques. Water Air Soil Poll 166:265-286

Li YH, Gregory S (1974) Diffusion of ions in sea water and in deep-sea sediments. Geochim Cosmochim Ac 38:703-714

Liu W, Coveney R, Chen J (2003) Environmental quality assessment on a river system polluted by mining activities. Appl Geochem 18:749 764

Lourino-Cabana B, Lesven L, Charriau A, Billon G, Ouddane B, Boughriet A (2011) Potential risks of metal toxicity in contaminated sediments of Deûle river in northern France. J Hazard Mater 186: 2129-2137

Lourino-Cabana B, Lesven L, Billon G, Denis L, Ouddane B, Boughriet A (2012) Benthic exchange of sedimentary metals (Cd, Cu, Fe, Mn, $\mathrm{Ni}$ and $\mathrm{Zn}$ ) in the Deule River (northern France). Environ Chem 9: 485-494

Lyons WB, Fitzgerald WF (1980) Trace metal fluxes to nearshore Long Island Sound sediments. Mar Pollut Bull 11:157-161

Petersen W, Wallman K, Pinglin L, Schroeder F, Knauth H (1995) Exchange of trace elements at the sediment-water interface during early diagenesis processes. Mar Fresh Water Res 46:19-26

Quinton JN, Catt JA (2007) Enrichment of heavy metals in sediment resulting from soil erosion on agricultural fields. Environ Sci Technol 41:3495-3500

Sakellari A, Plavšić M, Karavoltsos S, Dassenakis M, Scoullos M (2011) Assessment of copper, cadmium and zinc remobilization in Mediterranean marine coastal sediments. Estuar Coast Shelf S 91: $1-12$

Santos-Echeandia J, Prego R, Cobelo-García A, Millward G (2009) Porewater geochemistry in a Galician Ria (NW Iberian Peninsula): 
implications for benthic fluxes of dissolved trace elements $(\mathrm{Co}, \mathrm{Cu}$, $\mathrm{Ni}, \mathrm{Pb}, \mathrm{V}, \mathrm{Zn})$. Mar Chem 117:77-87

Santos-Echeandía J, Vale C, Caetano M, Pereira P, Prego R (2010) Effect of tidal flooding on metal distribution in pore waters of marsh sediments and its transport to water column (Tagus estuary, Portugal). Mar Environ Res 70:358-367

Schubauer-Berigan MK, Ankley GT (1991) The contribution of ammonia, metals and nonpolar organic compounds to the toxicity of sediment interstitial water from an Illinois River tributary. Environ Toxicol Chem 10:925-939

Sherman LA, Baker LA, Weir EP, Brezonik PL (1994) Sediment porewater dynamics of Little Rock Lake, Wisconsin: geochemical processes and seasonal and spatial variability. Limnol Oceangr-Meth 39:1155-1171

Sterckeman T, Douay F, Proix N, Fourrier H (2000) Vertical distribution of $\mathrm{Cd}, \mathrm{Pb}$ and $\mathrm{Zn}$ in soils near smelters in the north of France. Environ Pollut 107:377-389

Suresh G, Ramasamy V, Meenakshisundaram V, Venkatachalapathy R, Ponnusamy V (2011) Influence of mineralogical and heavy metal composition on natural radionuclide concentrations in the river sediments. Appl Radiat Isotopes 69:1466-1474

Tang WZ, Zhao Y, Wang C, Shan BQ, Cui JG (2013) Heavy metal contamination of overlying waters and bed sediments of Haihe Basin in China. Ecotox Environ Safe 98:317-323
Tang WZ, Shan BQ, Zhang H, Zhang W, Zhao Y, Ding Y, Rong N, Zhu X (2014) Heavy metal contamination in the surface sediments of representative limnetic ecosystems in eastern China. Sci Rep 4

Tang WZ, Zhang H, Shan BQ, Li SS (2015) Accumulation and risk assessment of sedimentary trace metals in response to industrialization from the tributaries of Fuyang River System. Environ Earth Sci 73:1975-1982

Ullman WJ, Sandstrom MW (1987) Dissolved nutrient fluxes from the nearshore sediments of Bowling Green Bay, central Great Barrier Reef lagoon (Australia). Estuar Coast Shelf S 24:289-303

Van Den Berg GA, Loch JG, Van Der Heijdt LM, Zwolsman JJ (1999) Mobilisation of heavy metals in contaminated sediments in the river Meuse, The Netherlands. Water Air Soil Poll 116:567-586

Wenholz M, Crunkilton R (1995) Use of toxicity identification evaluation procedures in the assessment of sediment pore water toxicity from an urban stormwater retention pond in Madison, Wisconsin. B Environ Contam Tox 54:676-682

Zhu H, Yan B, Pan X, Yang Y, Wang L (2011) Geochemical characteristics of heavy metals in riparian sediment pore water of Songhua River, Northeast China. Chinese Geogr Sci 21:195-203

Zwolsman JJ, Berger G, Van Eck G (1993) Sediment accumulation rates, historical input, postdepositional mobility and retention of major elements and trace metals in salt marsh sediments of the Scheldt estuary, SW Netherlands. Mar Chem 44:73-94 